\title{
Krystyna janicka Samoocena ruchliwości międzypokoleniowej w kontekście przemian struktury społecznej
}

\section{Self-perception of intergenerational mobility in light of changing social structure}

The aim of this paper is to discuss intergenerational mobility in Poland. Main attention is given to subjective perception of social mobility. The author is interested in how individuals perceive, explain and assess their social position and trajectory, and thereby how dynamics of social structure is intertwined with personal experience. She discusses social mobility in terms of objective measures and categories, with particular focus on comparison between respondents' social status and their fathers' status, and thereafter compares it with subjective perception of upward or downward social mobility. The analysis is based on three waves of POLPAN survey $(1988,2013,2018)$, an academic research project conducted by the Polish Academy of Sciences.

\begin{tabular}{r|l}
\hline DOI & https://doi.org/10.31268/StudiaBAS.2020.17 \\
\hline Słowa kluczowe & $\begin{array}{l}\text { ruchliwość międzypokoleniowa, ruchliwość społeczna, struktura } \\
\text { społeczna w Polsce, badania społeczne }\end{array}$ \\
\hline Keywords & $\begin{array}{l}\text { intergenerational mobility, social mobility, social structure in Poland, } \\
\text { social survey }\end{array}$ \\
\hline O autorce & $\begin{array}{l}\text { socjolog, doktor habilitowany, profesor Instytutu Filozofii i Socjologii } \\
\text { Polskiej Akademii Nauk } \bullet \text { kjanicka@ifispan.edu.pl • } \\
\text { ORCID 0000-0002-4355-2011 }\end{array}$ \\
\hline
\end{tabular}

\section{Wstęp}

Widoczna na poziomie makrosystemu dynamika struktur społecznych, która wynika ze zmian cywilizacyjnych i technologicznych, na poziomie jednostkowym przejawia się w zmianach pozycji społecznej poszczególnych osób. Zmiany te, nazwane ruchliwością społeczną, polegają na przemieszczaniu się jednostek w obrębie układu wertykalnego wyznaczonego przez istniejącą hierarchię grup i warstw społecznych. Zjawisko to można obserwować w dwóch planach: wewnątrzpokoleniowym, uwzględniającym kolejne fazy przebiegu życia jednostki, oraz międzypokoleniowym, który dotyczy porównywania osiągniętej przez jednostkę pozycji z pozycją ojca. Celem klasycznych analiz ruchliwości społecznej jest jej badanie w obydwu tych planach. Ze względu na wymierny charakter zmian pozycji społecznej ruchliwość względnie łatwo poddaje się obserwacji i ujęciu ilościowemu. Utrwalonym standardem badawczym jest ustalanie jej rozmiarów, określanie wzorów, w jakich się przejawia, i ich częstości, a niekiedy także zgłębianie uwarunkowań i konsekwencji'. Dla porządku należy odnotować, że ruchliwość całkowita („ruchliwość brutto”), identyfikowana z ogólną liczbą przypadków zmiany pozycji zachodzących w określonym czasie w danym społeczeństwie, ma dwojakiego rodzaju źródła. Ze względu na ten charakter uwarunkowań procesu zmian pozycji społecznej rozróżnia się w ujęciu analitycznym ruchliwość strukturalną i wymienną. Pierwsza jest pochodną moder-

1 S.M. Lipset, R. Bendix, Ruchliwość społeczna w społeczeństwie przemysłowym, PWN, Warszawa 1964. 
nizacyjnych przemian struktury zawodowej, które prowadzą do zmiany proporcji istniejących kategorii społeczno-zawodowych, a niekiedy także do zaniku pewnych grup i wyłonienia się nowych kategorii. Przykładem epoki, która przyniosła takie zmiany, był okres intensywnej industrializacji. W wypadku ruchliwości wymiennej („ruchliwość netto” lub „czysta”) istotą jest reguła zastępowalności jednych jednostek przez inne, co oznacza, że warunkiem dostępności danej pozycji jest uprzednie jej opuszczenie przez dotychczasowego „lokatora” (podobnie jak ma to miejsce w dziecięcej grze „w klasy”). Właśnie ten rodzaj ruchliwości świadczy o faktycznej elastyczności barier społecznych, a jej poziom jest traktowany jako wskaźnik otwartości struktury społecznej.

\section{Cel artykułu}

Ruchliwość społeczna, która jako proces dynamizujący strukturę społeczną jest ważnym wskaźnikiem zmiany społecznej, poza obiektywnym wymiarem - na którym skupia się głównie uwaga badaczy - ma również nie mniej doniosły aspekt subiektywny. Subiektywna ocena własnej kondycji społecznej i przekonanie co do kierunku dokonanej zmiany swojego położenia - ujmowanego w różnych społecznych i biograficznych kontekstach - są ważnymi elementami świadomości społecznej². Percepcja własnej ruchliwości względem pozycji rodziców, podobnie jak inne subiektywne korelaty zjawisk społecznych, nabiera szczególnego znaczenia w dobie radykalnych zmian strukturalnych, gdy w wyniku turbulencji politycznych i ekonomicznych - jako konsekwencji zmian ustrojowych - zmienia się logika funkcjonowania systemu społecznego. Badanie subiektywnego aspektu ruchliwości w postaci odczuć i ocen, jakie wywołują relacje i dystanse międzygrupowe, zmieniające się w perspektywie międzypokoleniowej, pozwala uchwycić sposób, w jaki dynamika makrostruktury społecznej odzwierciedla się w potocznej świadomości. Można bowiem założyć - w myśl teoretycznej tradycji wywodzącej się od Émile’a Durkheima i Marcela Maussa - że jednostka, dokonując oceny własnego położenia społecznego, odwołuje się do określonej wizji porządku społecznego i uznaje konstytuujące ów porządek kryteria hierarchizowania pozycji społecznych ${ }^{3}$. Należy przy tym dodać, że badając jednostkowe opinie, odnosimy je do określonych całości społecznych, które owe jednostki współtworzą na mocy wspólnie posiadanych cech. Poglądy, opinie, przekonania podzielane przez ogół jednostek należących do grup i kategorii społecznych ustrukturalizowanych według przyjętych kryteriów

2 Kwestiom subiektywnej ruchliwości międzypokoleniowej - zarówno w refleksji teoretycznej, jak i w badaniach empirycznych - poświęcano dotychczas znacznie mniej uwagi. Por. K. Janicka, Potoczna percepcja ruchliwości międzypokoleniowej. Analiza porównawcza lat 1976-1980 „,Przegląd Socjologiczny”, t. 35, Łódzkie Towarzystwo Naukowe, Łódź 1985. Problem subiektywnego znaczenia zmian pozycji społecznej częściej podejmują badacze ruchliwości wewnątrzpokoleniowej oraz procesów migracyjnych. Por.: I. Grabowska-Lusińska, Migrantów ścieżki zawodowe bez granic, Wydawnictwo Naukowe Scholar, Warszawa 2012; N. Lim, P. Mateju, Who Has Gotten Ahead after the Fall of Communism? The Case of the Czech Republic, „Sociologický časopis / Czech Sociological Review" 1995, vol. 3(2); A. Gugushvili, Intergenerational objective and subjective mobility and attitudes towards income differences: evidence from transition societies, „Journal of International and Comparative Social Policy" 2016, vol. 23, no. 3, https://doi.org/10.1080/21699763.2016.1206482.

3 W. Wesołowski, Typologia podziałów społecznych i identyfikacje jednostek, IFiS PAN, Warszawa 1989. 
określają zatem świadomość społeczną. Można więc uznać, że świadomość społeczna jest tożsama ze świadomością jednostek wchodzących w skład społeczeństwa ${ }^{4}$.

Przedmiot prezentowanych analiz stanowią percepcja ruchliwości międzypokoleniowej i jej ewolucja obserwowana w społeczeństwie polskim w latach 1988 oraz 2013 i 2018. Celem artykułu jest skonfrontowanie subiektywnie postrzeganej zmiany - w relacji do statusu ojca własnej pozycji społecznej z faktycznie dokonaną ruchliwością międzypokoleniową i określenie tendencji, które pod tym względem charakteryzują świadomość społeczną na przestrzeni ostatnich 30 lat. Problem badawczy, jaki wiąże się z tą kwestią, można wyrazić pytaniem: czy odzwierciedlony w świadomości społecznej wertykalny porządek pozycji społecznych odpowiada porządkowi obiektywnemu, określonemu przez zewnętrznego obserwatora na podstawie wymiernych wyznaczników położenia społecznego? Zestawienie subiektywnie określonej ruchliwości z faktycznie dokonaną międzygeneracyjną zmianą pozycji społecznej ma znaczną wartość diagnostyczną, jeśli chodzi o potoczną percepcję struktury społecznej, w szczególności tę jej sferę, która odnosi się do kwestii barier i dystansów międzygrupowych czy międzyklasowych. Subiektywne postrzeganie awansu lub degradacji czy też poczucie braku zmiany pozycji społecznej wskazują bowiem, jak odbierane są przez ludzi relacje i dystanse międzygrupowe i jak pojmowana jest wertykalność struktury społecznej. Badaniu subiektywnej ruchliwości i jej związku z mobilnością obiektywną towarzyszy przekonanie, że sposób, w jaki postrzega się własną ruchliwość w perspektywie wewnątrzpokoleniowej czy też międzypokoleniowej, jest lepszym predyktorem poglądów, preferencji i zachowań ludzi niż obiektywne wskaźniki ich położenia społecznego ${ }^{5}$.

Punktem wyjścia w badaniu wszelkiej ruchliwości społecznej jest przyjęcie określonej koncepcji struktury społecznej, niejako wyznaczającej przestrzeń dla dokonujących się zmian pozycji społecznej. Wynikająca z tej koncepcji kategoryzacja - w wypadku mobilności międzygeneracyjnej - stanowi podstawę określenia zarówno pochodzenia społecznego badanych, jak i osiąganych przez nich pozycji społecznych poprzez wskazanie przynależności do grup społecznych będących elementami tej struktury. Założenie o wertykalnym charakterze przyjętego grupowania umożliwia ocenę kierunku międzygeneracyjnych zmian pozycji społecznych w kategoriach awansu, degradacji czy stabilności. Określenie obiektywnej ruchliwości wynika zatem z przyjętych założeń, natomiast przekonania i oceny, jakie ludzie wiążą z ową ruchliwością, są funkcją całokształtu ich doświadczeń życiowych oraz potocznej wiedzy o rzeczywistości społecznej. Można więc przyjąć, że subiektywne odczucie i ocena zmiany własnej pozycji społecznej w stosunku do statusu ojca ujawnią postrzegane przez badanych dystanse międzygrupowe

4 Przyjęta w socjologii koncepcja jednostki (definiowana poprzez role społeczne, proces socjalizacji, miejsce w strukturze społecznej) oraz znaczenie, jakie dla jej psychospołecznego funkcjonowania ma otoczenie i społeczny kontekst, uzasadniają - na etapie analizowania i wyjaśniania zjawisk - przesuwanie ustaleń czynionych na poziomie jednostkowym na poziom agregowany. Kwestia ta dotyczy statusu ontologicznego i istoty metod badawczych w socjologii i od czasu Maxa Webera jest żywo dyskutowana w środowisku teoretyków i badaczy struktury społecznej i społeczeństwa. Por. J.H. Goldthorpe, O socjologii. Integracja badań i teorii, Wydawnictwo IFiS PAN, Warszawa 2012, s. 196-209.

5 A. Gugushvili, op. cit. 
oraz rozpoznawane społecznie kierunki awansu i degradacji, czyli - odsłonią obecne w świadomości społecznej wizje struktury społeczno-zawodowej czy klasowej. Można również uznać, że subiektywna ruchliwość i obserwowana w dłuższej perspektywie zmienność wyrażających ją przekonań są dobrym wskaźnikiem postrzegania przekształceń struktury społecznej i społecznej oceny kierunków jej ewolucji. Ale chodzi tu nie tylko o rozpoznanie potocznych wizji tej struktury. Przekonanie, iż dokonało się międzypokoleniowego awansu czy przeciwnie - doznało się degradacji, jest potencjalnym czynnikiem dobrostanu bądź dyskomfortu jednostki, co zgodnie z założeniami psychologii społecznej nie jest obojętne ani dla jej osobistego funkcjonowania, ani dla szerszych relacji społecznych.

\section{Ramy analizy empirycznej: horyzont czasowy i określenie segmentów klasowych}

Granicami wyznaczającymi okres historyczny, do którego odnoszą się analizowane dane, są lata 1988 oraz 2018. Pierwsza data przypada na czas zmierzchu socjalizmu z jego równościową ideologią i oficjalną bezklasowością oraz specyficznymi rozwiązaniami w sferze zarządzania, dystrybucji i polityki społecznej, a także deficytu wielu podstawowych dóbr. Przełom ustrojowy, który wkrótce nastąpił, przebiegał wieloetapowo i wyznaczał kolejne fazy przebudowy ustrojowej oraz gospodarczej w duchu neoliberalnej demokracji. Wprowadzanie zmian własnościowych i reformy rynkowej powodowało rozmaite dysfunkcje oraz generowało znaczne koszty społeczne, których natężenie zmieniało się w kolejnych okresach transformacji. Można przyjąć, że 2018 r. oznacza moment pełnej stabilizacji efektów transformacji systemowej i utrwalenia zasadniczych zmian w gospodarce oraz w obrębie struktury społecznej6. Uwzględnione w artykule dane odnoszące się do 2013 r., mimo iż dotyczą zaawansowanego etapu przekształceń systemowych, należy traktować - z jednej strony - jako swoisty układ odniesienia przy ocenie ruchliwości międzypokoleniowej w okresie przedtransformacyjnym, a z drugiej - jako podstawę służącą określeniu kierunku, w jakim już w okresie potransformacyjnym ewoluował proces międzygeneracyjnych zmian pozycji społecznych. Ze względu na oczywistą odmienność i specyfikę ustrojową okresu przed przełomem i po 1989 r. można oczekiwać, że samoocena ruchliwości międzypokoleniowej doświadczanej w ramach dwóch zasadniczo odmiennych modeli społeczno-ekonomicznych i na różnych etapach zmian systemu społecznego będzie się różniła co do kierunku i charakteru odczuwanej zmiany pozycji.

Podstawą empiryczną prezentowanych analiz są wypowiedzi respondentów dotyczące porównania własnej pozycji społecznej z pozycją społeczną ojca, uzyskane w badaniu POLPAN

6 Trudno o jednoznaczne stanowisko w sprawie daty wyznaczającej koniec transformacji w Polsce. Niektórzy argumentują, że cezurę taką wyznacza 2010 r. Dla uzasadnienia tej opinii przywołują dwa dokumenty Narodowy Program Foresight „Polska 2020” oraz raport Kancelarii Prezesa Rady Ministrów z 2009 r. Polska 2030: wyzwania rozwojowe.

7 POLPAN jest badaniem surveyowym, opartym na indywidualnych wywiadach, przeprowadzanym co 5 lat od 1988 r. na reprezentacji dorosłych mieszkańców kraju. Ostatnie badanie z tej serii pochodzi z 2018 r. Próby z poszczególnych lat można również traktować jako przekrojowe, ponieważ w każdej edycji tego wie- 
Gwoli ścisłości należy odnotować, że w badaniu z lat 2013 i 2018 pytanie skierowane do respondenta dotyczyło oceny jego pozycji społecznej względem pozycji, jaką miał ojciec w okresie, gdy był w wieku respondenta. Natomiast w badaniu z 1988 r. pytanie dotyczyło porównania własnej pozycji zawodowej z pozycją zawodową ojca w momencie, gdy respondent miał 14 lat $^{8}$. Nie wydaje się, że zmiana użytych sformułowań na tyle wpłynęła na treść pytań, by w zasadniczy sposób ograniczyć możliwość porównania danych. Ze względu na powszechnie uznawany, potwierdzony empirycznie związek pozycji społecznej z pozycją zawodową można założyć, że bez względu na użyte w pytaniu sformułowanie - w myśleniu respondenta porównującego się z ojcem będą uwzględniane zarówno wątki ściśle zawodowe, jak i kwestie dotyczące szerzej rozumianej sytuacji społecznej. Oba aspekty położenia społecznego (pozycja zawodowa i pozycja społeczna), choć analitycznie odrębne, w praktyce ściśle się zazębiają, kształtując potoczne wyobrażenia o miejscu respondenta w społeczeństwie i jego relacji wobec pozycji innych ludzi, w tym - rodziców. Przekonania ludzi nie wynikają wyłącznie z ich własnych preferencji i wyznawanych przez nich wartości, ale zależą od akceptowanych w najbliższym środowisku postaw i standardów odnoszących się do kwestii ogólniejszej natury, jak np.: dostępność rozmaitych dóbr, warunki zatrudnienia, poszanowanie pracowników, oparcie w instytucjach polityki społecznej czy możliwość wpływania na bieg spraw publicznych. Dlatego jest prawdopodobne, że samoocena ruchliwości międzypokoleniowej kształtuje się pod wpływem porównywania wielorakich aspektów położenia społecznego i uogólnionej oceny całokształtu warunków życiowych.

\section{Klasy społeczne a wertykalność struktury społecznej}

Struktura klasowa będąca podstawą nierówności społecznych w okresie gospodarki realnego socjalizmu różniła się w istotny sposób od struktury klasowej rodzącego się kapitalizmu. Po 1989 r. w nowych warunkach ustrojowych zmianie uległ skład struktury społecznej. Pojawiły się wówczas nowe kategorie, np. przedsiębiorcy, menadżerowie, podczas gdy niektóre dawne segmenty zanikły, np. dysponenci uspołecznionych środków produkcji, chłoporobotnicy ${ }^{9}$, bądź straciły swe znaczenie, np. wielkoprzemysłowa klasa robotnicza, z kolei inne - zyskały na znacze-

\footnotetext{
Ioletniego projektu - począwszy od 1998 r. - w celu zapewnienia reprezentatywności dla ludności powyżej 21 roku życia dolosowywano uzupełniające podpróby osób młodych. Szczegółowe informacje o badaniu są dostępne na stronie internetowej: www.polpan.org.

8 Pytanie dotyczące subiektywnej ruchliwości międzypokoleniowej w badaniu z 1988 r. (wersja Z) sformułowano następująco: (pytanie 93.) Jedno z poprzednich pytań dotyczyło P. ojca, gdy miał(a) P. 14 lat. Proszę jeszcze raz pomyśleć o zawodzie ojca z tamtego okresu i o swoim obecnym (lub ostatnim) zawodzie. Gdy porównuje P. swoja pozycję zawodowa z pozycja zawodowa ojca, to czy wydaje się P., że - ogólnie rzecz biorąc - P. obecna pozycja zawodowa jest: ... Natomiast w badaniach zrealizowanych w latach 2013 i 2018 pytanie dotyczące tej samej kwestii zadano w formie następującej: (pytanie M05.) Gdy porówna P. swoja pozycję społeczną z pozycja P. ojca, gdy był w P. wieku, to czy wydaje się P., że P. obecna pozycja jest: ... W obu pytaniach zastosowano takie same odpowiedzi: 1) o wiele wyższa niż pozycja ojca, 2) trochę wyższa niż pozycja ojca, 3) mniej więcej taka sama, 4) trochę niższa niż pozycja ojca, 5) o wiele niższa niż pozycja ojca, 6) nie wiem, trudno powiedzieć.

9 K.M. Słomczyński, K. Janicka, Pęknięta struktura społeczeństwa polskiego [w:] Polska. Ale jaka?, red. M. Jarosz, Oficyna Naukowa ISP PAN, Warszawa 2005, s. 127.
} 
niu, jak np. eksperci i pewne kategorie specjalistów. Zmieniła się także ranga kryteriów wyznaczających pozycję społeczną i określających przynależność klasową: własność, dochód czy pozycja w strukturze zarządzania zyskały na znaczeniu, natomiast takie wyznaczniki jak kwalifikacje w niektórych zawodach fizycznych czy zatrudnienie w dużych zakładach produkcyjnych utraciły swój potencjał alokacyjny. Gdy analizuje się wzór relacji łączących dochód, wykształcenie i status zawodowy, można dostrzec, że w kolejnych okresach zmian sytemu społeczno-ekonomicznego rozbieżność czynników statusu w odniesieniu do pewnych klas pogłębiła się. Na przykład wśród przedsiębiorców nadmiernie wzrosło - w stosunku do innych cech pozycji - nagradzanie, z kolei stopień niedostatecznego wynagradzania ekspertów zmniejszył się. Natomiast sytuacja wykonawczych pracowników umysłowych w tym względzie zmieniła się w odwrotnym kierunku. Analiza wspomnianych procesów daje podstawę - w zależności od potrzeb badawczych - do tworzenia typologii struktury społecznej o różnym stopniu uszczegółowienia ${ }^{10}$.

Strukturę społeczną definiujemy na użytek tego artykułu jako układ trzech segmentów, nazwanych odpowiednio: klasą wyższą, klasą środka oraz klasą niższą. Pojęcie klasy w ścisłym rozumieniu odnosi się wprost do stosunków dominacji i podporządkowania w sferze stosunków pracy i kontroli zasobów. Klasa społeczna - jako byt zakorzeniony w sieci relacji społecznych - ma ze swej natury charakter horyzontalny. Jednakże ze względu na empirycznie określone wartości statusu społeczno-ekonomicznego, jakie można przypisać poszczególnym klasom, zyskują one wymiar stratyfikacyjny ${ }^{11}$. Wertykalne uporządkowanie klasowych członów struktury społecznej daje podstawę do oceny kierunku międzygeneracyjnych przejść pomiędzy wyróżnionymi poziomami uwarstwienia w kategoriach awansu, degradacji bądź stabilności.

Klasy społeczne, które uwzględniamy w analizie subiektywnej ruchliwości, utworzono w drodze agregacji kategorii wyróżnionych w typologii opracowanej w badaniach POLPAN ${ }^{12}$. Względy

10 K.M. Słomczyński, K. Janicka, I. Tomescu-Dubrow, Przemiany struktury społecznej w Polsce: zmiany w latach 1978-2008 [w:] Modernizacja Polski. Struktury - agencje - instytucje, red. W. Morawski, Wydawnictwa Akademickie i Profesjonalne, Warszawa 2010; K. Janicka, Segregacja zawodowa ze względu na płeć w kontekście polskiego rynku pracy [w:] Kobiety - praca-podmiotowość. Refleksje socjologiczne, red. S. Kamińska-Berezowska, Wydawnictwo UŚ, Katowice 2020.

11 W badaniach nad stratyfikacją społeczną pozycja społeczna jest definiowana jako linearna kombinacja trzech elementów: statusu zawodowego, wykształcenia i dochodu. Przy ustalaniu statusu społecznego określonej kategorii lub klasy bierze się pod uwagę średnie wartości kryteriów wszystkich osób zaliczonych do danej klasy. Wyniki badań wskazują, że tak określona pozycja - mimo upływu czasu - pozostaje konstruktem o ustabilizowanej strukturze. Por. K.M. Słomczyński, K. Janicka, I. Tomescu-Dubrow, op. cit.; K. Janicka, K.M. Słomczyński, Od nierówności do polaryzacji: biegunowość struktury klasowej a różnice w postawach natury społecznej i politycznej [w:] Nowy ład? Dynamika struktur społecznych we współczesnych społeczeństwach, red. J. Grotowska-Leder, E. Rokicka, Wydawnictwo UŁ, Łódź 2013.

12 Założenia tej typologii i rezultaty stosowanych przy jej pomocy analiz empirycznych były szczegółowo przedstawiane w innych publikacjach. Por.: K.M. Słomczyński, K. Janicka, op. cit;; K.M. Słomczyński, K. Janicka, I. Tomescu-Dubrow, op. cit.; K. Janicka, K.M Słomczyński, op. cit. Typologia ta obejmowała: przedsiębiorców (zatrudniających siłę roboczą), menadżerów (wyższe kadry kierownicze), ekspertów (specjalistów), kierowników (bezpośrednich kontrolerów procesu pracy), pracowników samodzielnych (pracujących na własny rachunek), wykonawczych pracowników umysłowych, wykwalifikowanych pracowników fizycznych, niewykwalifikowanych pracowników fizycznych, rolników. 
porównawcze wymagają, aby w każdym z trzech badań były one identycznie zdefiniowane. Klasa wyższa obejmuje właścicieli, menadżerów i ekspertów; na klasę środka składa się personel administracyjno-biurowy, drobni przedsiębiorcy oraz pracownicy handlu i usług (nazwa celowa, chodzi o to, aby klasy środka nie utożsamiać z klasą średnią - zarówno tradycyjną, jak i nową); natomiast w skład klasy niższej wchodzą wszyscy pracownicy fizyczni bez względu na poziom kwalifikacji i dział zatrudnienia (w przemyśle, usługach i rolnictwie), a także rolnicy. Przyjmując taką typologię klas społecznych, odwołujemy się do głównych linii podziałów wyznaczających poziom zróżnicowania szeroko rozumianych szans życiowych. Oczywiście rola tych samych kategorii klasowych zmienia się w czasie, lecz mimo odrębnej logiki systemu socjalistycznego i systemu demokratyczno-liberalnego wprowadzonego po 1989 r., a także wbrew pewnym przesunięciom pozycji niektórych kategorii klasowych w układzie stratyfikacyjnym układ dystansów międzygrupowych nie uległ zasadniczej zmianie. Dodajmy, iż ograniczenie się do układu złożonego tylko z trzech klas społecznych było także podyktowane wymogami analizy empirycznej ze względu na konieczność zapewnienia odpowiedniej liczebności przypadków.

\section{Dynamika rzeczywistej ruchliwości międzypokoleniowej}

Dane w tabeli 1 pokazują, jak na przestrzeni 30 lat zmieniało się natężenie ruchliwości międzypokoleniowej faktycznie dokonanej w ramach struktury społecznej składającej się z segmentów klasowych, których charakterystykę wcześniej przedstawiono. Gdy pozycje społeczne osiągnięte przez badanych porównujemy z pozycjami ich ojców wedle kryteriów obiektywnych (w ramach przyjętego układu klasowego), okazuje się, że w każdym z trzech badanych okresów dominuje stabilność, oznaczająca pozostawanie dorosłych dzieci na tym samym poziomie w strukturze społecznej co ich ojcowie. Widać też, że przewaga owej immobilności nad przypadkami zmiany pozycji (awansem oraz degradacją) w nowych warunkach ustrojowych nieco zmalała. W 1988 r., w schyłkowej fazie socjalizmu, ponad połowa respondentów pozostawała w tym samym segmencie klasowym co ich ojcowie (56,8\%). W kolejnych latach, już po przełomie ustrojowym, proporcja osób stabilnych międzypokoleniowo zmniejszyła się prawie o 10 pkt proc. Jednocześnie w zbliżonym stopniu - niejako komplementarnie w stosunku do tej tendencji - awans międzypokoleniowy stał się częstszy. W latach 2013 i 2018 ruchliwości tego rodzaju doświadczyło nieco ponad $40 \%$ badanych. Jeśli chodzi o zmiany statusu w przeciwnym kierunku, jest regułą, że w społeczeństwach o nowoczesnej strukturze społeczno-zawodowej degradacja jest najmniej liczną formą międzypokoleniowej mobilności. W odpowiedzi na rosnące zapotrzebowanie na nowe rodzaje działalności i usług pojawiają się zawody wymagające bardziej złożonych i wyższych kwalifikacji. W wyniku tych zmian w kolejnych generacjach przybywa nowych kategorii aktywności, oferujących wyższe pozycje społeczne, podczas gdy zajęcia niżej lokowane związane z tradycyjnymi zawodami stopniowo zanikają lub giną. Tak też jest w przypadku społeczeństwa polskiego. W żadnym z uwzględnionych badań przypadki osiągnięcia pozycji niższej w stosunku do pozycji ojca nie osiągnęły pułapu wyższego niż 12,2\%, co zresztą miało miejsce w 2013 r., gdy zdążyły już okrzepnąć społeczno-ekonomiczne skutki zmiany ustroju i większego znaczenia jako czynniki społeczno-zawodowej selekcji nabrały kryteria rynkowe: przedsiębiorczość, odporność 
na ryzyko, innowacyjność. Odnotowane wtedy przypadki osiągania pozycji społecznej poniżej statusu dziedziczonego relatywnie nie były liczne. Jednakże w stosunku do poziomu, który charakteryzował koniec lat 80., liczba przypadków międzypokoleniowej degradacji po przełomie ustrojowym wzrosła prawie o połowę. Pamiętając o skali zmian, jakie w gospodarce i systemie dystrybucji rozmaitych dóbr wywołała transformacja, można stwierdzić, iż zaobserwowane w okresie potransformacyjnym nasilenie obu rodzajów międzypokoleniowej ruchliwości (zarówno awansu, jak i degradacji) kosztem przypadków stabilności wiązało się z dynamiką przekształceń społeczno-ekonomicznych charakterystycznych dla przełomu ustrojowego.

Tabela 1. Ruchliwość międzypokoleniowa według obiektywnych kryteriów określonych w ramach trójdzielnej struktury społecznej* w latach 1988, 2013, 2018 (w \%)

\begin{tabular}{|l|c|c|c|}
\hline \multicolumn{1}{|c|}{$\begin{array}{c}\text { Wariant rzeczywistej ruchliwości } \\
\text { międzypokoleniowej }\end{array}$} & \multicolumn{3}{|c|}{ Rok badania } \\
\cline { 2 - 4 } & $\mathbf{1 9 8 8}$ & $\mathbf{2 0 1 3}$ & $\mathbf{2 0 1 8}$ \\
\hline Stabilni & 56,8 & 47,0 & 46,9 \\
\hline Awansujący & 31,8 & 40,1 & 42,3 \\
\hline Zdegradowani & 8,6 & 12,2 & 10,9 \\
\hline Ogółem N = 100\% & 1412 & 879 & 1240 \\
\hline
\end{tabular}

* Liczebności uwzględnione w tabeli odnoszą się do zmian pozycji społecznej respondentów względem pozycji ich ojców, które polegały na przejściu pomiędzy trzema segmentami struktury społecznej (por. wyjaśnienia w tekście).

\section{Subiektywne poczucie ruchliwości międzypokoleniowej a usytuowanie w strukturze społecznej}

Istotną charakterystykę subiektywnej ruchliwości wyraża pytanie, w jaki sposób badani należący do różnych klas społecznych postrzegają i oceniają własną pozycję społeczną w stosunku do wyznaczonej statusem ojca pozycji dziedziczonej. Zakładając istnienie związku między przynależnością klasową a optyką poznawczą oraz systemem wartości będącym podstawą ocen, należałoby się spodziewać pewnego zróżnicowania opinii w zależności od posiadanego aktualnie statusu. Dane ilustrujące ten problem zawiera tabela 2. Wynika z nich, że w samoocenach przedstawicieli każdej z uwzględnionych klas - bez względu na poziom usytuowania w strukturze społecznej - przeważa poczucie międzypokoleniowego awansu ${ }^{13}$. Warto zwrócić uwagę, że przekonanie to (występujące w kolejnych okresach ze zmiennym natężeniem) jest z reguły najczęstsze w klasie wyższej, względnie wysokie w klasie środka i najmniej powszechne w klasie niższej. Jednakże niezależnie od klasy społecznej intensywność tego przekonania w miarę upływu czasu maleje. Przekonanie o posiadaniu wyższego niż ojciec statusu było najczęstsze

13 Liczbowe określenie omawianego w artykule subiektywnego poczucia uwzględnia łączne ujęcie dwóch odpowiedzi - własna pozycja społeczna respondenta w porównaniu z pozycją ojca jest trochę wyższa oraz dużo wyższa. 
Tabela 2. Ocena własnej pozycji społecznej w porównaniu z pozycją ojca według aktualnej przynależności klasowej - bez względu na rodzaj własnej ruchliwości - w latach 1988, 2013, 2018 (w \%)

\begin{tabular}{|c|c|c|c|c|c|c|c|}
\hline \multirow[b]{2}{*}{$\begin{array}{c}\text { Klasa } \\
\text { społeczna } \\
\text { respondenta }\end{array}$} & \multirow[b]{2}{*}{$\begin{array}{c}\text { Rok } \\
\text { badania }\end{array}$} & \multicolumn{4}{|c|}{ Ocena własnej pozycji społecznej } & \multirow{2}{*}{$\begin{array}{c}\text { Poczucie } \\
\text { awansu: } \\
\text { ocena } \\
\text { łączna } \\
(3+4)\end{array}$} & \multirow[b]{2}{*}{$\begin{array}{l}\text { Ogółem } \\
N=100 \%\end{array}$} \\
\hline & & $\begin{array}{c}\text { niższa* } \\
\text { (1) }\end{array}$ & $\begin{array}{c}\text { taka } \\
\text { sama } \\
(2)\end{array}$ & $\begin{array}{c}\text { trochę } \\
\text { wyższa } \\
\text { (3) }\end{array}$ & $\begin{array}{c}\text { o wiele } \\
\text { wyższa } \\
\text { (4) }\end{array}$ & & \\
\hline \multirow[t]{3}{*}{ Klasa wyższa } & 1988 & 12,8 & 16,8 & 34,4 & 36,0 & 70,4 & 125 \\
\hline & 2013 & 17,6 & 26,1 & 23,9 & 32,4 & 56,3 & 142 \\
\hline & 2018 & 9,6 & 27,0 & 32,0 & 31,5 & 63,5 & 178 \\
\hline \multirow[t]{3}{*}{ Klasa środka } & 1988 & 10,9 & 23,0 & 47,3 & 18,9 & 66,2 & 488 \\
\hline & 2013 & 25,1 & 22,5 & 32,4 & 19,9 & 52,3 & 386 \\
\hline & 2018 & 15,7 & 30,9 & 29,1 & 24,3 & 53,4 & 612 \\
\hline \multirow[t]{3}{*}{ Klasa niższa } & 1988 & 12,4 & 32,2 & 42,3 & 13,1 & 55,4 & 799 \\
\hline & 2013 & 25,9 & 32,5 & 21,1 & 14,5 & 35,6 & 351 \\
\hline & 2018 & 19,5 & 36,1 & 29,9 & 14,6 & 44,5 & 452 \\
\hline \multirow[t]{3}{*}{ Ogółem } & 1988 & 11,9 & 27,6 & 43,3 & 17,1 & 60,4 & 1412 \\
\hline & 2013 & 24,2 & 27,1 & 28,9 & 19,8 & 48,7 & 879 \\
\hline & 2018 & 16,1 & 32,2 & 29,8 & 21,8 & 51,6 & 1242 \\
\hline
\end{tabular}

* Oceny: „niższa” i „dużo niższa” zostały ujęte łącznie.

w 1988 r., nawet w klasie określonej jako niższa ponad połowa badanych przed przełomem ustrojowym miała poczucie międzypokoleniowego awansu (55,4\%). W okresie potransformacyjnym samooceny dotyczące ruchliwości uległy znacznej korekcie. Poczucie awansu w 2013 r. okazało się mniej powszechne, najbardziej osłabło w klasie niższej, w której już tylko 1/3 badanych deklarowała wyższość swojej pozycji względem pozycji ojca. Choć w późniejszym okresie skłonność do przypisywania sobie awansu międzypokoleniowego ponownie wzrosła, to przekonanie o poprawie swojego statusu w stosunku do statusu ojca w żadnej klasie nie przekroczyło poziomu z okresu przedtransformacyjnego. Obserwowaną dynamikę postrzegania swojego statusu w kategoriach międzygeneracyjnego awansu można wiązać zapewne ze zmieniającym się kontekstem sytuacyjnym, który tworzyły specyficzne warunki społeczno-ekonomiczne w każdym z dwóch ustrojowo odmiennych okresach. O skali zmian, które przełom ustrojowy wniósł do realnych procesów strukturalizacji oraz do potocznego myślenia o ładzie społecznym, może świadczyć również nasilenie poczucia degradacji międzypokoleniowej widoczne w każdej klasie bez względu na poziom jej usytuowania w strukturze społecznej. W 2013 r. niemal co szósty respondent należący do klasy wyższej, a w przypadku środkowego i najniższego szczebla struktury społecznej co czwarty, deklarował, iż jego pozycja społeczna w porównaniu z pozycją 
ojca obniżyła się w mniejszym lub większym stopniu (odpowiednio: 17,6\%, 25,1\%, 25,9\%). Nasilenie poczucia międzypokoleniowej degradacji - szczególnie znamienne w przypadku osób o wysokiej pozycji społecznej - częściowo może wynikać z częstszego odczuwania relatywnej deprywacji, będącej efektem różnicowania się sytuacji społeczno-zawodowej poszczególnych członków tej klasy. Może także się wiązać z narastającym poczuciem niepewności nie tylko w sferze zawodowej, ale także gdy chodzi o możliwości spełnienia oczekiwań i rosnących aspiracji w innych dziedzinach życia.

\section{Subiektywna i obiektywna ruchliwość międzypokoleniowa - zbieżność obu wymiarów oraz rodzaje ich rozbieżności}

W celu ukazania związku rzeczywistej ruchliwości z jej subiektywnym odczuciem deklarowane przez respondentów oceny międzypokoleniowej zmiany swojej pozycji społecznej zestawiono z konkretnymi wariantami obiektywnie określonej ruchliwości pomiędzy trzema segmentami klasowymi. Dane ilustrujące ten związek zamieszczono w tabeli 3. Prawidłowości, które można odczytać z układu tych danych, dotyczą kierunków współzależności i wzorów powiązań między oboma wymiarami międzypokoleniowej ruchliwości. Wzory owe należy rozumieć jako przejaw regularności, z jaką danemu rodzajowi (obiektywnie ustalonej międzypokoleniowej zmiany pozycji) jest przypisywana określona samoocena.

Patrząc pod kątem tych właściwości, należy stwierdzić, że żaden wariant obiektywnej mobilności nie spotyka się z jednoznaczną, odpowiadającą jego rzeczywistemu znaczeniu subiektywną ewaluacją. Widać również, że każdej formie międzygeneracyjnej zmiany pozycji społecznej odpowiada większe lub mniejsze zróżnicowanie samoocen respondentów, w tym także całkowicie przeciwstawnych wobec obiektywnej zmiany subiektywnych kwalifikacji. Obiektywna stabilność bywa niekiedy postrzegana jako awans lub jako degradacja, z kolei awans bywa uznawany za stabilność lub degradację. Zdarza się również, że faktyczna degradacja w subiektywnym odbiorze jest traktowana jako awans. Wyjaśnienie tego rodzaju rozbieżności nie jest sprawą prostą. Psychospołeczne mechanizmy kształtowania się percepcji rozmaitych sfer rzeczywistości społecznej są niezwykle złożone. Ich empiryczne rozwikłanie i weryfikacja wymagałyby przygotowania odrębnego projektu badawczego, którego jednym z celów byłoby zgłębianie uwzględnianych przez jednostkę kryteriów oceny ${ }^{14}$.

14 Interesującą próbę uchwycenia kryteriów wyjaśniających sposób, w jaki respondenci oceniają swoją ogólną pozycję społeczną, podjęto w badaniach łódzkich z lat 1967-1976 i 1980. Zestawiono wtedy odpowiedzi na pojedyncze pytanie o ogólną pozycję społeczną z jej ocenami formułowanymi ze względu na wykształcenie, status zawodowy i dochód. Analityczna procedura badania samooceny według kryteriów szczegółowych nie przyniosła jednak spodziewanych rezultatów. Okazało się, że wykształcenie, charakter pracy, dochód i inne szczegółowe kryteria nie wyjaśniają więcej niż 30\% zmienności odpowiedzi na pytanie o ocenę ogólnej pozycji społecznej. K.M. Słomczyński, G. Kacprowicz, Subiektywna ocena pozycji społecznej [w:] Strukturalizacja społeczeństwa polskiego, red. W. Wesołowski, K. Janicka, K.M. Słomczyński, Wydawnictwo IFiS PAN, Warszawa 2017, s. 218. Rezultat taki odnosi się do oceny swojej pozycji w społeczeństwie (w porównaniu z innymi ludźmi), ale dowodzi też złożoności problemu wyjaśniania samoocen oraz konieczności rozszerzania pola badawczego nad psychologicznymi aspektami struktury społecznej. 
Tabela 3. Subiektywna ocena pozycji społecznej w porównaniu z pozycją ojca w zależności od wariantu rzeczywistej ruchliwości międzypokoleniowej (stabilności, awansu, degradacji) w latach 1988, 2013, 2018 (w \%)

\begin{tabular}{|c|c|c|c|c|c|c|c|}
\hline \multirow[b]{2}{*}{$\begin{array}{c}\text { Wariant } \\
\text { rzeczywistej } \\
\text { ruchliwości }\end{array}$} & \multirow[b]{2}{*}{$\begin{array}{c}\text { Rok } \\
\text { badania }\end{array}$} & \multicolumn{4}{|c|}{$\begin{array}{c}\text { Ocena własnej pozycji społecznej } \\
\text { w porównaniu z ojcem }\end{array}$} & \multirow{2}{*}{$\begin{array}{c}\text { Przewaga } \\
\text { poczucia } \\
\text { awansu } \\
\text { nad } \\
\text { degrada- } \\
\text { cją [(3 + } \\
4)-1]\end{array}$} & \multirow[b]{2}{*}{$\begin{array}{l}\text { Ogółem } \\
N=100 \%\end{array}$} \\
\hline & & $\begin{array}{l}\text { niższa* } \\
\text { (1) }\end{array}$ & $\begin{array}{c}\text { taka } \\
\text { sama } \\
(2)\end{array}$ & $\begin{array}{l}\text { trochę } \\
\text { wyższa } \\
\text { (3) }\end{array}$ & $\begin{array}{c}\text { o wiele } \\
\text { wyższa } \\
\text { (4) }\end{array}$ & & \\
\hline \multirow[t]{3}{*}{ Stabilni } & 1988 & 11,7 & 33,3 & 42,3 & 12,7 & 43,3 & 802 \\
\hline & 2013 & 25,4 & 32,0 & 28,1 & 14,2 & 16,9 & 413 \\
\hline & 2018 & 16,4 & 39,2 & 30,3 & 14,1 & 27,4 & 581 \\
\hline \multirow[t]{3}{*}{ Awansujący } & 1988 & 7,8 & 17,8 & 49,7 & 24,7 & 66,6 & 449 \\
\hline & 2013 & 16,4 & 20,1 & 34,8 & 28,7 & 47,1 & 359 \\
\hline & 2018 & 7,7 & 24,4 & 33,8 & 34,2 & 60,3 & 524 \\
\hline \multirow[t]{3}{*}{ Zdegradowani } & 1988 & 25,4 & 25,4 & 30,3 & 18,0 & 22,9 & 122 \\
\hline & 2013 & 45,8 & 31,8 & 12,1 & 10,3 & $-23,4$ & 107 \\
\hline & 2018 & 48,1 & 32,6 & 11,9 & 7,4 & $-28,8$ & 135 \\
\hline \multirow[t]{3}{*}{ Ogółem } & 1988 & 11,9 & 27,6 & 43,3 & 17,1 & 48,5 & 1412 \\
\hline & 2013 & 24,2 & 27,1 & 28,9 & 19,8 & 24,5 & 879 \\
\hline & 2018 & 16,2 & 32,3 & 29,8 & 21,9 & 35,5 & 1240 \\
\hline
\end{tabular}

* Oceny „niższa” i „dużo niższa” zostały ujęte łącznie.

Opinie, oceny i poglądy określające świadomość społeczną, niezależnie od formy, jaką przybierają, poza wrażliwością na kontekst psychologiczno-społeczny mają też własną dynamikę. Odnosi się to również do percepcji międzypokoleniowej mobilności. Na podstawie danych w tabeli 3 można prześledzić, jak w trakcie 30 lat kształtowały się samooceny międzypokoleniowych zmian pozycji społecznej. Wystarczy spojrzeć na zmieniające się pod względem skali i kierunku relacje między rzeczywistym wymiarem zmian pozycji społecznej badanych a deklarowanymi przez nich samoocenami. Szczególną uwagę warto zwrócić na przekonania respondentów uznanych za międzypokoleniowo stabilnych. Okazuje się, że w tej grupie badanych poczucie awansu międzypokoleniowego było bardziej oczywiste niż przekonanie, że własny status społeczny jest taki sam jak status ojca. Należy zwrócić uwagę, że poczucie awansu wbrew faktycznej stabilności najczęściej deklarowano przed zmianą systemu (55\%). Później, w nowych warunkach społeczno-ekonomicznych, to przekonanie osłabło (42,3\% w 2013 r.). Natomiast poczucie degradacji - choć znacznie rzadziej wyrażane - ewoluowało w przeciwnym kierunku (mimo rzeczywistej stabilności). W 2013 r. co czwarty badany spośród stabilnych określał swoją pozycję społeczną jako niższą w porównaniu z pozycją swego ojca, co w stosunku do okresu sprzed 
zmiany sytemu oznaczało dwukrotny wzrost poczucia międzypokoleniowej degradacji $(25,4 \%$ wobec 11,7\% w 1988 r.). Jednakże podczas następnych 5 lat (2013-2018), mimo umacniania się systemu rynkowego i wzrostu jego specyficznych wymagań wobec uczestników rynku pracy, przekonanie o międzypokoleniowej degradacji w grupie osób immobilnych osłabło, wzrosła natomiast odpowiadająca stanowi faktycznemu świadomość stabilności swojej pozycji społecznej.

Jeśli chodzi o postrzeganie własnej ruchliwości przez osoby, które międzypokoleniowo awansowały, dane pokazują, że ich samoocena w przeważającej mierze odpowiada rzeczywistej sytuacji. Zgodność tego rodzaju nie budzi zdziwienia, potwierdza raczej przystawalność osobistej wizji struktury społecznej do jej obiektywnej postaci. Jednakże sytuacja taka nie wyczerpuje wachlarza możliwych odczuć, jakie towarzyszą obiektywnie dokonanemu awansowi. Oto u osób, które de facto awansowały, zaskakuje nasilające się z biegiem lat poczucie stabilności czy wręcz skrajne przekonanie o degradacji międzypokoleniowej, które - jak pokazują dane dotyczące 2013 r. - nie jest bynajmniej wykluczone. Przypadki tego rodzaju rozziewu między subiektywną ruchliwością a jej rzeczywistym przejawem zdarzały się najczęściej w fazie stabilizowania się skutków intensywnego wdrażania neoliberalnej doktryny w sferze rynku pracy i dystrybucji usług publicznych. Przekonanie, iż doświadczyło się degradacji, w 2013 r. wyrażało niemal dwa razy więcej osób, które według obiektywnych kryteriów awansowały, niż miało to miejsce przed zmianą systemu (16,4\% wobec 7,8\%). W świetle tych danych okazuje się, że schyłkowy okres socjalizmu - mimo wszelkich napięć i charakteryzujących go niedoborów - prezentuje się jako czas, kiedy awans międzypokoleniowy był najsilniej odczuwany nie tylko przez faktycznie awansujących (74,4\% w 1988 r.), ale nawet przez osoby, które nie zdołały osiągnąć porównywalnej z ojcem pozycji. Natomiast w okresie potransformacyjnym (w warunkach nowego ładu społeczno-gospodarczego) poczucie międzypokoleniowego awansu społecznego wśród osób, które faktycznie tego dokonały, wyraźnie się osłabiło (63,5\% w 2013 r.). Można dodać, że w kolejnych latach w tej grupie badanych niejako na przekór rzeczywistości umacniało się poczucie stabilności. W 2018 r. co czwarty respondent - mimo obiektywnego awansu międzypokoleniowego - uznawał się za osobę międzypokoleniowo immobilną. Powody takiej ewaluacji pozycji społecznej są zapewne wielorakie. Wśród nich można wskazać chociażby: zmianę znaczenia tradycyjnych kryteriów wyznaczania społecznej hierarchii, różnego rodzaju trudności adaptacyjne wywołane transformacją ustrojową oraz komplikowanie się stosunków społecznych i nieprzejrzystość relacji między klasowymi segmentami struktury społecznej. Wymienione zjawiska wynikają nie tylko z przekształceń własnościowych czy przestawienia gospodarki i rynku pracy na nowe neoliberalne tory. Ich źródłem są także zmiany cywilizacyjne - postępująca indywidualizacja oraz komplikowanie się form pracy i stylu życia.

Odrębną kategorię percepcji ruchliwości międzypokoleniowej tworzą przekonania towarzyszące oczywistej - w świetle obiektywnych kryteriów - degradacji społecznej. W 1988 r. niemal połowa respondentów o tym typie ruchliwości międzygeneracyjnej określała swoją pozycję jako wyższą od pozycji ojca (48,3\%) wbrew obiektywnie doznanej degradacji. Charakterystyczne jest, że to poczucie awansu, pozostające w wyraźnej sprzeczności z kierunkiem realnie doznanej ruchliwości, wydatnie osłabło po przełomie ustrojowym i wykazywało tendencję do dalszego spadku w kolejnych latach. W 2013 r. częstość tego rodzaju rozbieżności między subiektywną 
a rzeczywistą ruchliwością w porównaniu z wcześniejszym okresem zmniejszyła się dwukrotnie, choć nadal 22,4\% spośród osób, które rzeczywiście doznały degradacji, deklarowało poczucie awansu. Jednocześnie w okresie postransformacyjnym w kontraście do tej tendencji nasiliło się odczuwanie degradacji, co oznaczało tym samym wzrost odpowiedniości między oboma wymiarami ruchliwości (45,8\% w 2013 r. i 48,1\% w 2018 r.). Większa skłonność do realistycznej oceny swojej pozycji w porównaniu ze statusem ojca i uznawania zgodnie ze stanem rzeczywistym własnej degradacji międzypokoleniowej sygnalizuje, że skutki przemian społeczno-ekonomicznych, które przyniosła transformacja ustrojowa, znajdują odzwierciedlenie w świadomości społecznej. Wśród skutków owej transformacji można wymienić takie zjawiska strukturalne, jak: rosnące dystanse społeczne, usztywnienie barier międzygrupowych, wielość możliwych płaszczyzn różnicowania się sytuacji życiowej oraz wspomnianą wyżej zmianę znaczenia tradycyjnych kryteriów wyznaczania hierarchii społecznej.

\section{Uwagi końcowe}

Celem artykułu było skonfrontowanie subiektywnie ocenianej ruchliwości międzygeneracyjnej z jej obiektywnym wymiarem i pokazanie, jak z biegiem lat zmienia się myślenie o własnej pozycji społecznej porównywanej z pozycją ojca. Definiując obiektywną ruchliwość jako rezultat zmiany pozycji społecznej polegającej na przekraczaniu granic między trzema segmentami klasowymi, skupiono się na najbardziej syntetycznym ujęciu problemu. Analizowana rozbieżność między samoocenami a rzeczywistą ruchliwością dowodzi, że międzypokoleniowe zmiany pozycji społecznej, które - wydałoby się - można jednoznacznie określić jako awans, degradację lub - w przypadku braku zmiany - stabilność, w odbiorze społecznym są oceniane w sposób bardziej zróżnicowany. Jeśli weźmie się pod uwagę psychologiczny mechanizm i wielość czynników warunkujących przekonania, zjawisko takie wyda się naturalne. Gdy jednak analizuje się przejawy owej rozbieżności, jej konkretne formy i zmieniającą się w określonym rytmie intensywność, trudno nie uznać walorów poznawczych takiego ujmowania problemu. Jednym z nich jest np. ujawnienie, w jakich segmentach struktury społecznej rozziew pomiędzy subiektywną a rzeczywistą ruchliwością międzygeneracyjną jest największy, co stanowi wskazówkę przy badaniu psychologicznych następstw tego stanu rzeczy. Znaczenie ma również rozpoznanie dynamiki owej rozbieżności, szczególnie gdy chodzi o przewidywanie, w jakich kręgach społeczeństwa narastać mogą frustracja i resentymenty. Międzypokoleniowe zmiany statusu społecznego - zarówno awans, jak i degradację - można analizować bardziej szczegółowo, uwzględniając odpowiednio rozbudowaną skalę dystansu dzielącego porównywane pozycje społeczne: pozycję osiągniętą przez jednostkę w toku własnej kariery oraz pozycję dziedziczoną, określoną przez status społeczny ojca. Ze względu na to kryterium wyróżnia się ruchliwość krótkodystansową i długodystansową. Ta pierwsza oznacza sytuację, gdy awans lub degradacja następują w wyniku przejścia między kategoriami zajmującymi sąsiednie miejsca na drabinie stratyfikacyjnej (ang. mobility „step by step”). Natomiast ruchliwość długodystansowa ma miejsce wtedy, gdy międzypokoleniowe zmiany statusu społecznego polegają na przechodzeniu pomiędzy kategoriami społecznymi usytuowanymi na oddalonych od siebie czy wręcz krańcowych 
poziomach drabiny stratyfikacyjnej. Takie ujęcie międzygeneracyjnych zmian pozycji społecznej niewątpliwie pozwoliłoby bardziej precyzyjnie uchwycić empiryczne wzory wzajemnych relacji pomiędzy obiektywnym wymiarem ruchliwości międzypokoleniowej i jego subiektywną oceną. Zasadnicze znaczenie w badaniu skali i wzorów ruchliwości społecznej ma jednak przyjęcie określonej konceptualizacji struktury społecznej, która wyznacza ramy jej ilościowej i jakościowej charakterystyki. W kontekście tych uwag należałoby zaznaczyć, że warunkiem kontynuacji analiz, które pogłębiłyby kwestie poruszane w artykule, jest dostępność danych uwzględniających odpowiednio duże próby badawcze. Interesujące byłoby również włączenie do przyszłego projektu pytań odnoszących się do kryteriów, jakimi kierują się respondenci, dokonując porównania własnej pozycji społecznej z pozycją ojca.

\section{Bibliografia}

Goldthorpe J.H., O socjologii. Integracja badań i teorii, Wydawnictwo IFiS PAN, Warszawa 2012.

Grabowska-Lusińska I., Migrantów ścieżki zawodowe bez granic, Wydawnictwo Naukowe Scholar, Warszawa 2012.

Gugushvili A., Intergenerational objective and subjective mobility and attitudes towards income differences: evidence from transition societies, „J ournal of International and Comparative Social Policy” 2016, vol. 23, no. 3, https:// doi.org/10.1080/21699763.2016.1206482.

Janicka K., Potoczna percepcja ruchliwości międzypokoleniowej. Analiza porównawcza lat 1976-1980, „Przegląd Socjologiczny", t. 35, Łódzkie Towarzystwo Naukowe, Łódź 1985.

Janicka K., Segregacja zawodowa ze względu na płeć w kontekście polskiego rynku pracy [w:] Kobiety - praca-podmiotowość. Refleksje socjologiczne, red. S. Kamińska-Berezowska, Wydawnictwo UŚ, Katowice 2020.

Janicka K., Zawód i praca - dwa wymiary strukturalizacji społecznej [w:] Rozwarstwienie społeczne, red. A. Kiersztyn, D. Życińska-Ciołek, K.M. Słomczyński, Wydawnictwo IFiS PAN, Warszawa 2017, https://doi.org/10.26485/ ps/2018/67.4/9.

Janicka K., Słomczyński K.M., Od nierówności do polaryzacji: biegunowość struktury klasowej a różnice w postawach natury społecznej i politycznej [w:] Nowy ład? Dynamika struktur społecznych we współczesnych społeczeństwach, red. J. Grotowska-Leder, E. Rokicka, Wydawnictwo UŁ, Łódź 2013.

Lim N., Mateju P., Who Has Gotten Ahead after the Fall of Communism? The Case of the Czech Republic, "Sociologický časopis / Czech Sociological Review" 1995, vol. 3(2).

Lipset S.M., Bendix R., Ruchliwość społeczna w społeczeństwie przemysłowym, PWN, Warszawa 1964.

Słomczyński K.M., Janicka K., Pęknięta struktura społeczeństwa polskiego [w:] Polska. Ale jaka?, red. M. Jarosz, Oficyna Naukowa ISP PAN, Warszawa 2005.

Słomczyński K.M., Janicka K., Tomescu-Dubrow I., Przemiany struktury społecznej w Polsce: zmiany w latach 19782008 [w:] Modernizacja Polski. Struktury - agencje - instytucje, red. W. Morawski, Wydawnictwa Akademickie i Profesjonalne, Warszawa 2010.

Słomczyński K.M., Kacprowicz G., Subiektywna ocena pozycji społecznej [w:] Strukturalizacja społeczeństwa polskiego, red. W. Wesołowski, K. Janicka, K.M. Słomczyński, Wydawnictwo IFiS PAN, Warszawa 2017.

Wesołowski W., Typologia podziałów społecznych i identyfikacje jednostek, IFiS PAN, Warszawa 1989. 